\title{
EXPRESS METHOD FOR ASSESSING PROTEOLYSIS IN CHEESE AND AROMATIC ADDITIVES WITH CHEESE FLAVOR
}

\author{
Dmitriy S. Myagkonosov*, Dmitriy V. Abramov, Elena G. Ovchinnikova, Valentina N. Krayushkina
}

All-Russian Scientific Research Institute of Butter- and Cheesemaking Branch of V. M. Gorbatov Federal Research Center for Food Systems of RAS, Uglich, Yaroslavl Region, Russia

KEY WORDS:

cheese, enzyme-modified cheese, proteolysis, OPA, Kjeldahl method

\section{ABSTRACT}

The method based on the determination of the amount of active amino groups using o-Phthaldialdehyde (OPA method) can be applied in practice to assess accurately the degree of proteolysis in cheeses. The work establishes that the OPA method gives results that strictly correlate $\left(R^{2}>0.80, p<0.01\right)$ with the results of assessing the degree of proteolysis by the Kjeldahl method. The results of the OPA method, expressed in the absorption intensity of the colored sample at a wavelength of $340 \mathrm{~nm}$ (OD340), can be converted to the content of soluble nitrogenous substances in cheese (WSN), using the calibration relationship between these indicators.

The accuracy of the calibration relationship between WSN and OD340 can be increased $\left(R^{2}>0.91, p<0.01\right)$ when using the OPA method in relation to a homogeneous group of cheeses produced by the same technology using the same type of milk clotting enzyme and lactic acid starter culture and having a similar shape of the molecular mass distribution of proteolysis products.

The OPA method can be used to assess the content of proteolysis products, which form cheese flavor, in EMC The results of assessing the degree of proteolysis by the OPA method (OD340) are proportional to both the total content of soluble nitrogen and the proportion of nitrogenous substances in it with a mass of less than $0.5 \mathrm{kDa}$, which make the greatest contribution to the formation of cheese flavor.

The advantage of using the OPA method for assessing proteolysis in cheeses and EMC instead of the Kjeldahl method is a simpler measurement procedure and the possibility of studying more samples in less time.

FUNDING: The article was published as part of the research topic No. 0585-2019-0010 of the state assignment of the V. M. Gorbatov Federal Research Center for Food Systems of RAS

\section{Introduction}

The traditional criterion for assessing proteolysis in cheeses is the ratio of the amount of water soluble nitrogen (WSN) to the amount of total nitrogen (TN) in the cheese with the determination of nitrogen forms by the Kjeldahl method. This is a laborious and time-consuming method. Alternatively, other methods for assessing proteolysis based on other physical principles, in particular colorimetric methods, can be used. Colorimetric methods are fast, accurate and not time-consuming.

Colorimetric methods for assessing proteolysis based on the formation of colored complexes as a result of the reaction of special reagents (dyes) with reactive groups of nitrogenous substances formed during proteolysis are proposed. The degree of coloration can be used to assess the degree of proteolysis in the studied cheeses. Among the methods most widely used by researchers to study proteolysis in cheeses, there are methods based on the reaction of free amino groups:

$\square$ with 2,4,6-trinitrobenzenesulphonic acid (TNBS), which reacts with primary amines, forming colored compounds having an absorption maximum at $420 \mathrm{~nm}[1,2]$;

$\square$ with ninhydrin, which, as a result of a specific reaction with alpha-amino groups, leads to the formation of a bright violet color, the degree of which can be estimated on a spectrophotometer at a wavelength of $570 \mathrm{~nm}$ [3];

$\square$ with o-Phthaldialdehyde (OPA). Reaction between amino groups and OPA in presence of a reducing agent such as 2-mercaptoethanol forming a colored compound detectable at $340 \mathrm{~nm}$ in a spectrophotometer [4,5,6,7].

The method for assessing the degree of proteolysis with the OPA reagent (hereinafter referred to as the OPA method) is widely used in the analysis of the degree of protein hydrolysis in protein hydrolysates. The method is highly accurate and reproducible $[8,9]$.

The advantages of the OPA method are:

$\square$ sufficiently short reaction time of staining ( $2 \mathrm{~min}$ ) before measurements, which provides a comfortable analysis for the laboratory assistant;

use of inexpensive VIS-range spectrophotometers $(\lambda \geqslant 340 \mathrm{~nm})$ and inexpensive optical glass cuvettes;

$\square$ no need for heating and long-term keeping of heated samples before assessing the degree of staining on a spectrophotometer, in contrast to methods using TNBS and ninhydrin [10]. Despite the obvious advantages, the OPA method has not yet found widespread use in assessing the degree of cheese maturity. This is due to the well-established tradition of assessing the degree of proteolysis in cheeses by the WSN content, as well as the absence of a strict relationship between the optical density of the colored complexes at a wavelength of $340 \mathrm{~nm}$ (OD340) and the WSN content in cheeses. For the introduction of the OPA method into widespread use, it is necessary to develop a method for accurately recalculating the OD340 indicator obtained using the OPA method into the WSN indicator obtained using the Kjeldahl method.

\section{Materials and methods}

\subsection{Materials}

The studies used cow's milk from one supplier-manufacturer - AgriVolga LLC (Yaroslavl Region, Uglichsky District, Burmasovo village). In the production of cheeses, a lactic acid starter culture was used, consisting of a set of cultures of Lactocococcus lactis subsp. lactis, Lactocococcus lactis subsp. cremoris, Lactocococcus lactis subsp. diacetylactis, based on bacterial 
concentrate BK-Uglich-No.4 and BK-Uglich-No.5A (FGBNU Experimental Biofabrika, Russia) with preliminary activation of the culture on sterilized milk. Milk coagulation was performed using milk clotting enzymes (MCE) of the brands: Chy-max ${ }^{\circledR}$ Powder Extra 2235 NB, Naturen ${ }^{\circledR}$ Extra 220 NB (Chr Hansen A / S, Denmark), and Fromase ${ }^{\circledR} 750$ XLG (DSM Food Specialties, France). Proteolytic enzymes were used for the production of enzymemodified cheese: Neutrase ${ }^{\circledR} 0.8$ L, Flavourzyme ${ }^{\circledR} 1000$ L (Novozymes A / S, Denmark), as well as lipolytic enzymes: of microbial origin - Palatase ${ }^{\circledR} 20000$ L (Novozymes A / S, Denmark) and of animal origin - a lipase preparation of calves, lambs, kids (Caglificio Clerici Spa, Italy).

To assess the degree of proteolysis by the OPA method, the following reagents were used: o-Phthaldialdehyde for fluorescence $\geqslant 99.0 \%$ (Sigma, Product No. 79760), dodecyl sodium sulfate $99 \%$ for ion pair chromatography (J\&K, Cat. No. 953543), sodium tetraborate 99\% (Aldrich, Product No. 221732), dithiothreitol 99\% for molecular biology (J\&K, Cat. No. 926470), L-serine Pharmaceutical Secondary Standard (Supelco, Product No. PHR1103).

\subsection{Methods}

\subsubsection{Production of Cheese}

An Edam type cheese was produced with a fat content in dry matter of $45 \%$. Table 1 shows the technological regulations for the cheese production.

Technological regulations for the cheese production

\begin{tabular}{lc}
\hline \multicolumn{1}{c}{ Stage of the technological process } & Process parameters \\
\hline Mass fraction of fat in milk mixture & $2.8-3.0 \%$ \\
\hline Milk pasteurization & $72{ }^{\circ} \mathrm{C} ; 10 \mathrm{sec}$ \\
\hline Calcium chloride dose & $\begin{array}{c}\text { Based on } 35 \mathrm{~g} \text { of anhydrous } \\
\text { salt per } 100 \mathrm{~kg} \text { of milk }\end{array}$ \\
\hline Dose of lactic acid starter culture & $0.5 \%$ \\
\hline Milk acidity before coagulation & $\mathrm{pH} 6.42 \pm 0.02$ \\
\hline Milk clotting enzyme dose * & $1380 \pm 180 \mathrm{IMCU} / 100 \mathrm{~kg}$ \\
of milk
\end{tabular}

Fresh cheese was salted by immersion in an $18 \%$ salt solution for 1 day at a temperature of $4 \pm 2{ }^{\circ} \mathrm{C}$. After salting, the cheeses were packed under vacuum (negative pressure 1 bar; evacuation time $20 \mathrm{~s}$ ) in bags made of AMIVAC CH-B polymer film (ATLANTIS-PAK, Russia). The cheeses ripening of half of the batch of cheeses was carried out at a temperature of $6-8{ }^{\circ} \mathrm{C}$, the other half of the batch of cheeses - at a temperature of $10-12^{\circ} \mathrm{C}$. Ripening duration was 45 days. After ripening, the cheeses were stored at a temperature of $3 \pm 1{ }^{\circ} \mathrm{C}$. Samples for analysis were taken after 2 and 10 months of storage.

\subsubsection{Production of Enzyme-Modified Cheese}

Aromatic additives with a cheese flavor ("enzyme-modified cheese" - EMC) were produced according to the two-step approach method described in [12] with a number of modifications. A mixture was prepared from fresh cheese curd having a $\mathrm{pH}$ of $6.35 \pm 0.05$, Na caseinate, a complex phosphate additive "Phonakon" (Reatex, Russia) consisting of a mixture of phosphate saltsemulsifiers (E451i, E450i, E450ii, E339i, E339ii) and water. Mass fraction of dry matter in the mixture is $42 \%$, fat in dry matter of the mixture is $40 \%$. The mixture was homogenized using an immersion blender for $3 \mathrm{~min}$ in a water bath at a temperature of $(80-85)^{\circ} \mathrm{C}$. The resulting mixture was cooled to a temperature of $45 \pm 1{ }^{\circ} \mathrm{C}$, after which proteolytic enzyme preparations were added to the mixture: Neutrase ${ }^{\circledR} 0.8 \mathrm{~L}(0.6 \% \mathrm{w} / \mathrm{w})$ and Flavourzyme ${ }^{\circledR} 1000 \mathrm{~L}(0.2 \% \mathrm{w} / \mathrm{w})$.

After stirring, the mixture was incubated at $48 \pm 1^{\circ} \mathrm{C}$ for 4 hours. After 4 hours, the mixture was stirred again and lipase preparations were added to it: Palatase ${ }^{\circledR} 20000 \mathrm{~L}(0,4 \% \mathrm{w} / \mathrm{w})$ or animal lipases $(0,5 \% \mathrm{w} / \mathrm{w})$. After stirring, the fermentation of the mixture was continued at a temperature of $48 \pm 1^{\circ} \mathrm{C}$ for 36 hours. After the completion of the fermentation, the mixture was heat-treated in a water bath at a temperature of $(80-85)^{\circ} \mathrm{C}$ for 30 minutes to inactivate enzymes and microorganisms. The finished EMC was transferred into glass containers with caps and stored at a temperature of $3 \pm 1^{\circ} \mathrm{C}$.

\subsubsection{Methods for Studying the Cheese Properties}

Determination of active acidity $-10 \mathrm{~g}$ of grated cheese was ground in a mortar with $10 \mathrm{~cm}^{3}$ of deionized water; active acidity was determined on a $\mathrm{pH}-150 \mathrm{MI} \mathrm{pH}$ meter (Measuring equipment, Russia).

The determination of the mass fraction of moisture was carried out by drying at a temperature of $102 \pm 2{ }^{\circ} \mathrm{C}$ according to the Russian state standard GOST 3626-73.

Determination of the mass fraction of total and soluble nitrogen was carried out by the Kjeldahl method according to the Russian state standard GOST R54662-2011.

The degree of proteolysis in cheeses was expressed as a percentage of the absolute content of water soluble nitrogen (WSN) relative to the absolute content of total nitrogen (TN).

\section{Sample preparation}

The extraction of water soluble nitrogen from the cheeses was carried out according to the method [13] in the modification: $20 \mathrm{~g}$ of grated cheese was mixed with $40 \mathrm{~cm}^{3}$ of deionized water, homogenized on a FSH-2A high-speed homogenizer (Jiangsu Jinyi Instrument Technology Company Limited, China) for $1 \mathrm{~min}$. The resulting mixture (slurry) was transferred to a volumetric flask and the volume was made up to $100 \mathrm{ml}$ with deionized water. The mixture was kept at $40^{\circ} \mathrm{C}$ for $1 \mathrm{~h}$ with continuous shaking for $200 \mathrm{~min}^{-1}$ on an SK-O180-E orbital shaker (DLAB Scientific Co., Ltd, China). The samples were centrifuged at $3000 \mathrm{~g}$ for $30 \mathrm{~min}$. After centrifugation, the samples were cooled to $4^{\circ} \mathrm{C}$ and the upper fat layer was removed. The supernatant was separated and filtered on cellulose acetate filters with a pore size of $0.45 \mu \mathrm{m}$ (Vladipor, Russia). The resulting filtrate was used to determine the content of water soluble nitrogen according to Kjeldahl and to analyze the molecular mass distribution. To study the OPA method, the obtained extract was mixed with deionized water in a ratio of $1: 9(\mathrm{vol} / \mathrm{vol})$.

The extraction of water soluble nitrogen from EMC was carried out after preliminary defatting. Defatting was carried out with ice-cold hexane according to the modification method [14]. For this, $20 \mathrm{~g}$ of EMC was mixed with $60 \mathrm{ml}$ of hexane in a $500 \mathrm{ml}$ Erlenmeyer flask with a ground stopper and kept in a refrigerator at minus $18^{\circ} \mathrm{C}$ for $1 \mathrm{~h}$ with periodic shaking. A portion of 
hexane with the extracted fat was decanted, after which a fresh portion of hexane was added, and the defatting procedure was repeated. The fat was extracted 3 times. The defatted sample was dried under a stream of air at room temperature for $3 \mathrm{~h}$, after which another cycle of defatting and drying was repeated. To obtain an aqueous extract, a weighed portion of $2.5 \mathrm{~g}$ of dried EMC was mixed with $50 \mathrm{ml}$ of deionized water, kept for $30 \mathrm{~min}$ with continuous shaking, and then homogenized on a high-speed homogenizer. The mixture was transferred to a volumetric flask, made up to $100 \mathrm{ml}$ with deionized water and filtered through filter paper. The resulting filtrate was used to determine the content of water soluble nitrogen according to Kjeldahl. To analyze the molecular mass distribution, the obtained extract was mixed with deionized water in a ratio of $4: 6(\mathrm{vol} / \mathrm{vol})$ and filtered on cellulose acetate filters with a pore size of $0.45 \mu \mathrm{m}$. To study the OPA method, the obtained extract was mixed with deionized water in a ratio of $1: 9(\mathrm{vol} / \mathrm{vol})$.

\section{Molecular mass distribution}

Determination of the molecular mass distribution of soluble nitrogenous substances in the aqueous extract from cheeses and EMC was carried out by high-resolution gel filtration method using a Superose 12 10/300 GL column (GE Healthcare, Sweden). The eluent is an aqueous solution of $0.05 \mathrm{M} \mathrm{Na}_{2} \mathrm{HPO}_{4}$ $+0.15 \mathrm{M} \mathrm{NaCl}$, the flow rate of the eluent is $0.5 \mathrm{ml} / \mathrm{min}$; detector wavelength $-280 \mathrm{~nm}$. The column was calibrated according to the retention time of protein substances with a known molecular mass: IgG (180 kDa), aldolase (158 kDa), BSA (69 kDa), ovoalbumin (43 kDa), $\beta$-Lg (36.0 kDa), $\alpha$-La (14.4 kDa), cytochrome C (12.3 kDa), tryptophan (0.204 kDa). The calibration graph was approximated by the logarithmic regression model [15]. The molecular mass distribution was expressed as the fraction of the peak area of the nitrogen fraction from the total area of the chromatogram. Results are expressed as the percentage of peptide material in various molecular mass ranges [16].

\section{Degree of hydrolysis by the OPA method (OD340)}

The degree of hydrolysis (DH) was determinated according to Nielsen et al [8] with modifications. The OPA reagent was prepared as follows: $4.020 \mathrm{~g}$ anhydrous sodium tetraborate and $200 \mathrm{mg}$ dodecyl sodium sulfate (SDS) were dissolved in $150 \mathrm{~mL}$ deionized water. $160 \mathrm{mg}$ o-Phthaldialdehyde 97\% (OPA) was dissolved in $4 \mathrm{~mL}$ ethanol. The OPA solution was then transferred quantitatively to the above-mentioned solution. $176 \mathrm{mg}$ dithiothreitol 99\% (DTT) was added to the solution by rinsing with deionized water. The solution was made up to $200 \mathrm{~mL}$ with deionized water.

Optical density was determined in a mixture of $3 \mathrm{ml}$ of OPA reagent and $0.4 \mathrm{ml}$ of the test sample. A mixture of $3 \mathrm{ml}$ of OPA reagent and $0.4 \mathrm{ml}$ of deionized water was used as a blank. The absorption was determined on a spectrophotometer of LEKI model SS1207UV (MEDIORA OY, Finland) in quartz cuvettes with an optical path length of $10 \mathrm{~mm}$ at a wavelength of $\lambda=340 \mathrm{~nm}$. The absorbance values for the interaction of amino groups with OPA were taken after 2 min standing. The result was expressed as the concentration of meqv serine of $\mathrm{NH}_{2}$ group in a liter of the sample solution based on the calibration straight line built in the range of serine concentrations 0-2.0 meqv/L.

Mathematical processing was performed using Microsoft Excel and StatSoft Statistica software packages.

\section{Results and discussion}

Table 2 shows the indicators of the composition of cheeses and EMC studied during the experiment.
Table 2

Indicators of the composition of cheeses and EMC

\begin{tabular}{lcc}
\hline \multicolumn{1}{c}{ Indicator } & $\begin{array}{c}\text { Cheeses } \\
(\mathbf{n}=\mathbf{1 6})\end{array}$ & $\begin{array}{c}\text { EMC } \\
\mathbf{( n = 7 )}\end{array}$ \\
\hline Mass fraction of dry matter, \% & $59.28 \pm 1.76$ & $43.19 \pm 0.55$ \\
\hline Mass fraction of fat in dry matter, \% & $46.03 \pm 0.44$ & $38.99 \pm 0.18$ \\
\hline Mass fraction of total nitrogen, \% & $4.51 \pm 0.21$ & $2.88 \pm 0.15$ \\
\hline Mass fraction of soluble nitrogen, \% & $1.24 \pm 0.30$ & $2.21 \pm 0.20$ \\
\hline Active acidity, pH & $5.25 \pm 0.06$ & $5.70 \pm 0.21$
\end{tabular}

Average content of nitrogenous fractions with molecular mass:

$\begin{array}{ccc}<0,5 \mathrm{kDa} & 14 \% & 34 \% \\ 0,5-1 \mathrm{kDa} & 14 \% & 20 \% \\ 1-2 \mathrm{kDa} & 14 \% & 23 \% \\ 2-5 \mathrm{kDa} & 15 \% & 17 \% \\ 5-10 \mathrm{kDa} & 8 \% & 5 \% \\ 10-20 \mathrm{kDa} & 10 \% & 1 \% \\ >20 \mathrm{kDa} & 24 \% & 0 \%\end{array}$

Note: the table shows Mean \pm Standard Deviation.

OPA reacts with free amino groups of peptides and free amino acids. The results of the OPA method (OD340) depend on both the amount of protein material (WSN) in the test sample and the degree of hydrolysis of the protein material that proportional concentration to free of amino groups. The results of the Kjeldahl method (nitrogen content in the sample) depend only on the amount of protein material in the sample and do not depend on its degree of hydrolysis. Due to the different physical nature of the action of these two methods, it is necessary to substantiate the applicability of the OPA method to control the degree of proteolysis in cheeses and EMC, proving the possibility of recalculating the values of the OPA method into the values obtained by the Kjeldahl method.

Table 3 shows the degree of correlation between the results of the OPA method and the indicators of proteolysis of cheeses and EMC.

Correlation between the variables of OPA method and the indicators of proteolysis in samples of cheeses and EMC

\begin{tabular}{ccccc}
\hline \multirow{2}{*}{ Variable } & \multicolumn{2}{c}{ Cheese (n=16) } & \multicolumn{2}{c}{ EMC (n=7) } \\
\cline { 2 - 5 } & WSN & OD340 & WSN & OD340 \\
WSN & 1.00 & 0.91 & 1.00 & 0.89 \\
\hline $\begin{array}{c}\text { Amount of peptide material with } \\
\text { a diapason of molecular weight }\end{array}$ & & & & \\
\hline$<0.5 \mathrm{kDa}$ & 0.12 & 0.15 & 0.14 & 0.51 \\
\hline $0.5-1 \mathrm{kDa}$ & 0.41 & 0.52 & -0.50 & -0.57 \\
$1-2 \mathrm{kDa}$ & 0.39 & 0.51 & -0.39 & -0.71 \\
\hline $2-5 \mathrm{kDa}$ & 0.74 & 0.68 & 0.58 & 0.56 \\
\hline $5-10 \mathrm{kDa}$ & 0.30 & 0.35 & 0.40 & 0.18 \\
$10-20 \mathrm{kDa}$ & -0.53 & -0.66 & 0.13 & -0.03 \\
\hline $20 \mathrm{kDa} *$ & -0.44 & -0.49 & - & - \\
\hline
\end{tabular}

Note:

WSN - water soluble nitrogen, OD340 - optical density at wavelength $340 \mathrm{~nm}$.

$\mathrm{R}$ - correlation coefficient; $\mathrm{p}$ - significance level.

* Peptides with mass $>20 \mathrm{kDa}$ are absent in EMC.

As follows from the data in Table 3, the results of the OPA method (OD340) for cheeses and EMC depend on the total con- 
tent of nitrogenous substances (WSN) and the molecular mass distribution of hydrolysis products.

\section{Assessment of proteolysis in cheeses}

In cheeses, OD340 has a strong correlation with WSN $(\mathrm{R}=0.91)$. The strong correlation between OD340 and WSN is due to the specificity of proteolysis in cheeses. During the proteolysis process in cheeses, proteins and large peptides are broken down and converted into smaller peptides and free amino acids. The number of fractions with a mass of more than $10 \mathrm{kDa}$ decreases, and the number of fractions with a mass of less than $10 \mathrm{kDa}$ increases. In the studied cheeses, peptides with a mass of less than $10 \mathrm{kDa}$ leave most (on average $65 \%$, see Table 2) of compounds of water soluble nitrogen (WSN), therefore, WSN correlates with the content of fractions weighing less than $10 \mathrm{kDa}$.

At the same time, with an increase in the degree of proteolysis in cheeses, the increase in the content of individual nitrogenous fractions occurs in a balanced way and no fraction prevails over the other. Figure 1 (1) shows chromatograms of the molecular mass distribution of proteolysis products in cheeses with different degrees of proteolysis. Figure 1 (2) shows the dependence of OD340 on the WSN content in cheese.

For the reasons described above, much of the variation of the response variable in OD340 can be attributed to variation in the single influencing factor (WSN). Therefore, the regression equation describing the dependence of OD340 on WSN has a high coefficient of determination $\mathrm{R}^{2}=0.83$. The results obtained coincide with the results of the studies by Rohm et al [7], which revealed a strong relationship $\left(\mathrm{R}^{2}=0.965\right)$ between the content of free $\mathrm{NH}_{2}$ groups in Swiss cheese, determined by the OPA method, and WSN, determined by the Kjeldahl method.

Some of the variation in the OD340 response variable is related to the influence of other influencing factors that are not taken into account in the regression equation shown in Figure 1.2. The results of the correlation analysis (Table 3) show that OD340 significantly correlates with the content of individual peptide fractions with different molecular masses in cheeses. This indicates that differences in molecular mass distribution between cheeses will influence on the form of regression dependence of the OD340 on WSN.
The reasons for the differences in molecular mass distribution can be associated with the different specificity of proteolysis in cheeses. Most of the proteolysis products in cheeses such as Gouda and Cheddar are formed as a result of the action of MCE. Especially on Cheddar and Gouda, the enzymes in rennet (chymosin or rennet substitute) are mainly responsible for initial proteolysis and the production of most of the water-soluble $\mathrm{N}$ [17].

In the production of cheeses, MCEs of different origins were used: recombinant calf chymosin (Chy-max ${ }^{\circledR}$ Powder Extra 2235 $\mathrm{NB}$ ), calf rennet (Naturen ${ }^{\circledR}$ Extra $220 \mathrm{NB}$ ) and microbial rennet based on the Rhyzomucor miehei protease (Fromase ${ }^{\circledR} 750$ XLG). MCEs of different origins have different proteolytic activity and different specificity of proteolysis. Microbial rennet has the highest proteolytic activity among other MCE types; they break down a large number of peptide bonds in casein, which leads to the accumulation of an increased amount of peptides with low molecular mass. Recombinant chymosin has low proteolytic activity and cleaves a limited number of peptide bonds in casein. Among the products of proteolysis in cheeses with recombinant chymosin, peptides with a large molecular mass prevail. Calf rennet (a mixture of chymosin and pepsin) occupies an intermediate position in proteolytic activity between microbial rennet and recombinant chymosin [18]. Figure 2 (1) shows the molecular mass distribution of proteolysis products in cheeses produced with different types of MCEs and having the same degree of proteolysis (WSN/TN $=31 \%$ ).

Earlier, it was suggested that for cheeses that have different shapes of molecular mass distribution, there will be a different form of regression dependence of OD340 on WSN. Since the shape of the molecular mass distribution of proteolysis products depends on the type of MCE used for the cheese production, in order to test the proposed assumption, the total data sample for all cheeses $(n=16)$ was divided into 3 subsamples for cheeses produced with different types of MCE: Naturen (n=8), Chy-max $(n=4)$ and Fromase $(n=4)$. For each subgroup, a regression relationship between OD340 and WSN was constructed. The results are presented in Figures 2 (2) - 2 (4).

\section{Assessment of proteolysis in EMC}

When assessing the degree of proteolysis in EMC using the OPA method (Table 3), the OD340 value significantly correlates
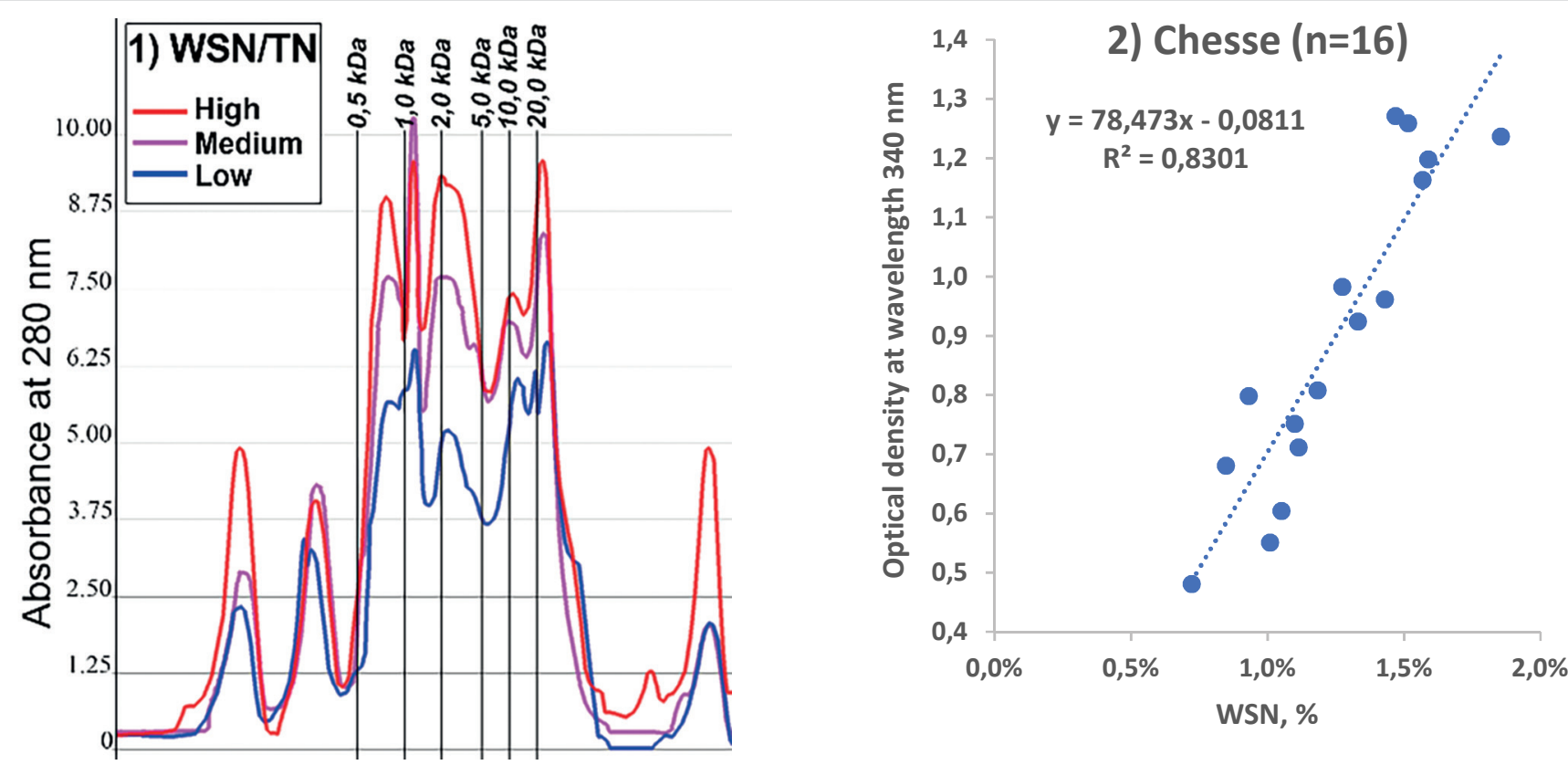

Figure 1. 1) Molecular mass distribution of proteolysis products in cheese samples with minimum, average and maximum proteolysis levels in the sample: Low (WSN/TN = 17\%); Medium (WSN/TN = 28\%); High (WSN/TN = 39\%) and 2) dependence of the degree of staining with OPA reagent (OD340) on the content of water soluble nitrogen (WSN) in cheeses. 

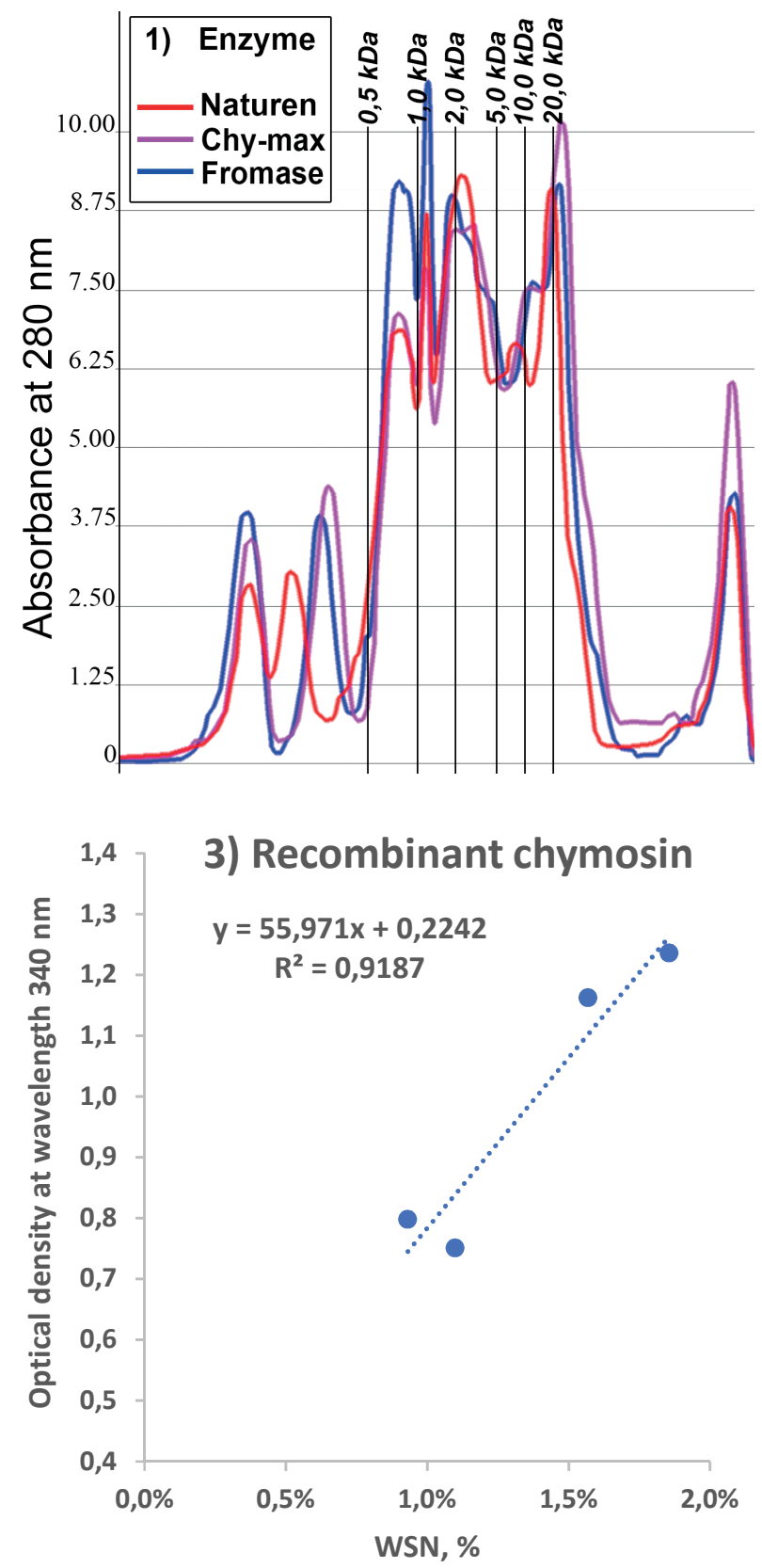
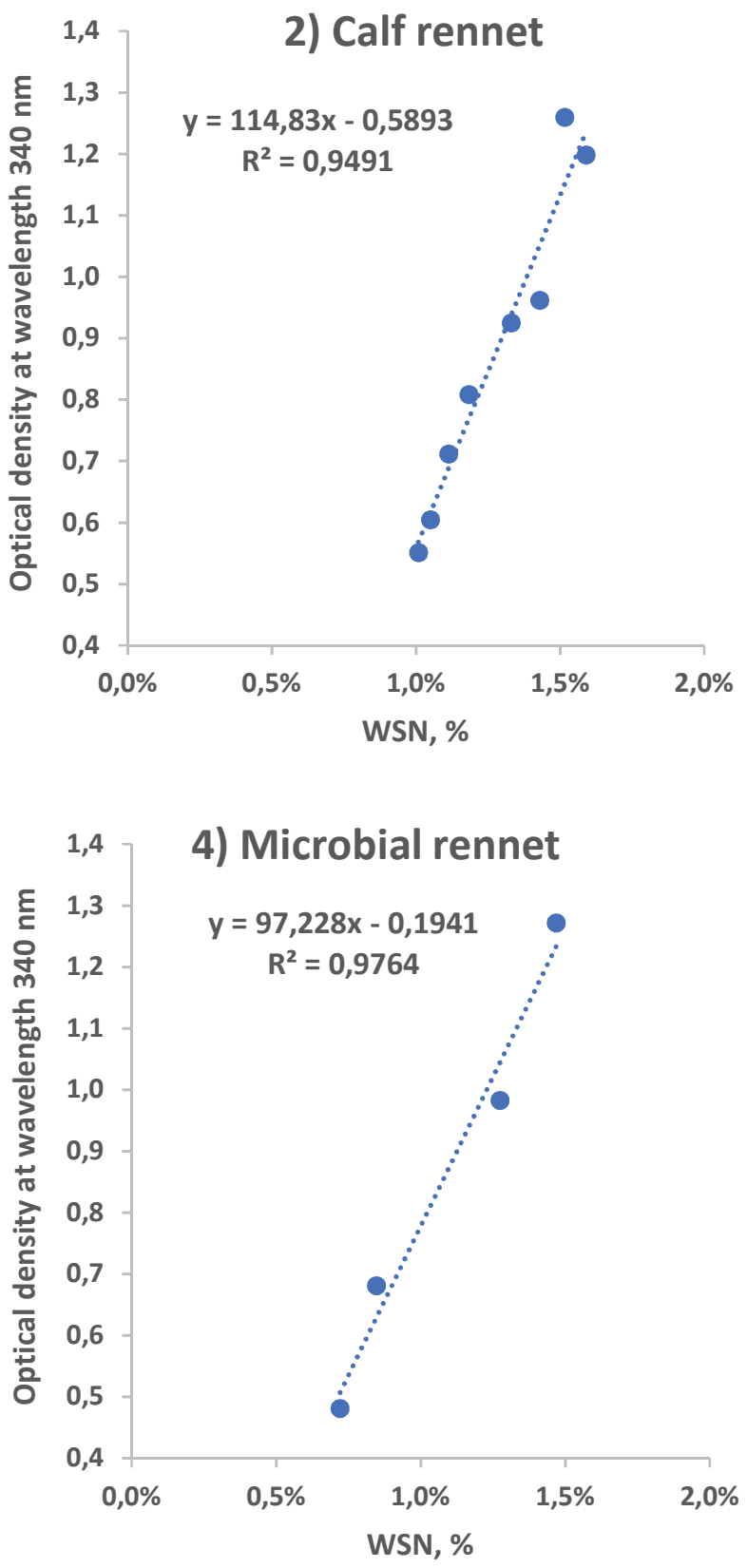

Figure 2. 1) Molecular mass distribution in cheese samples produced using different types of MCE and having the same degree of proteolysis (WSN/TN = 31\%); and 2), 3, 4) - the dependence of the degree of staining with the OPA reagent (OD340) on the content of water soluble nitrogen (WSN) for cheeses with different types of MCE

with WSN $(\mathrm{R}=0.89)$ and with the content of nitrogenous fractions with a mass of less than $5 \mathrm{kDa}$.

Proteolysis in EMC has a specificity that differs from proteolysis in cheeses: with an increase in the degree of proteolysis, the content of nitrogenous fractions with a mass of less than $0.5 \mathrm{kDa}$ increases to the greatest extent in EMC (Figure 3 (1)). The EMC production technology is optimized to obtain the maximum amount of proteolysis products with a molecular mass of less than $0.5 \mathrm{kDa}$. In particular, the Flavourzyme ${ }^{\circledR}$ enzyme preparation is intended for this, which contains exopeptidases that break down protein to form free amino acids.

The hydrolysis products of casein, small peptides and free amino acids, have a pronounced taste and make a direct contribution to the formation of cheese flavor $[19,20]$. High levels of low molecular weight peptides and free amino acids (FAA) important in cheese flavor [12]. As a result of numerous studies, it was found that among the products of proteolysis, peptides with a mass of less than $0.5 \mathrm{kDa}$ make the greatest contribution to the formation of the flavor of Cheddar cheese [17]. Commercial EMC samples are characterized by a WSN/TN ratio of up to $80 \%$ and higher, with a proportion of proteolysis products with a molecular mass $<0.5 \mathrm{kDa}$ up to $90 \%$ [21]. Therefore, the absolute content of peptide material with a molecular mass of $<0.5 \mathrm{kDa}$ can be selected as a criterion for assessing proteolysis in EMC. Amount of peptide material with a $\mathrm{MW}<0.5 \mathrm{kDa}$ is calculated using the following equations:

$$
A_{0,5 k D a}=S_{0,5 k D a} \times W S N
$$

where:

WSN - water soluble nitrogen content in the sample (g/100 g);

$S_{0.5 \mathrm{kDa}}$ - part area under chromatographic curve in region molecular mass $<0.5 \mathrm{kDa}(\%)$.

Figure 3 (2) shows the regression dependence of the degree of staining with OPA reagent (OD340) on the amount of peptide material with a MW $<0.5 \mathrm{kDa}$ in EMC. 

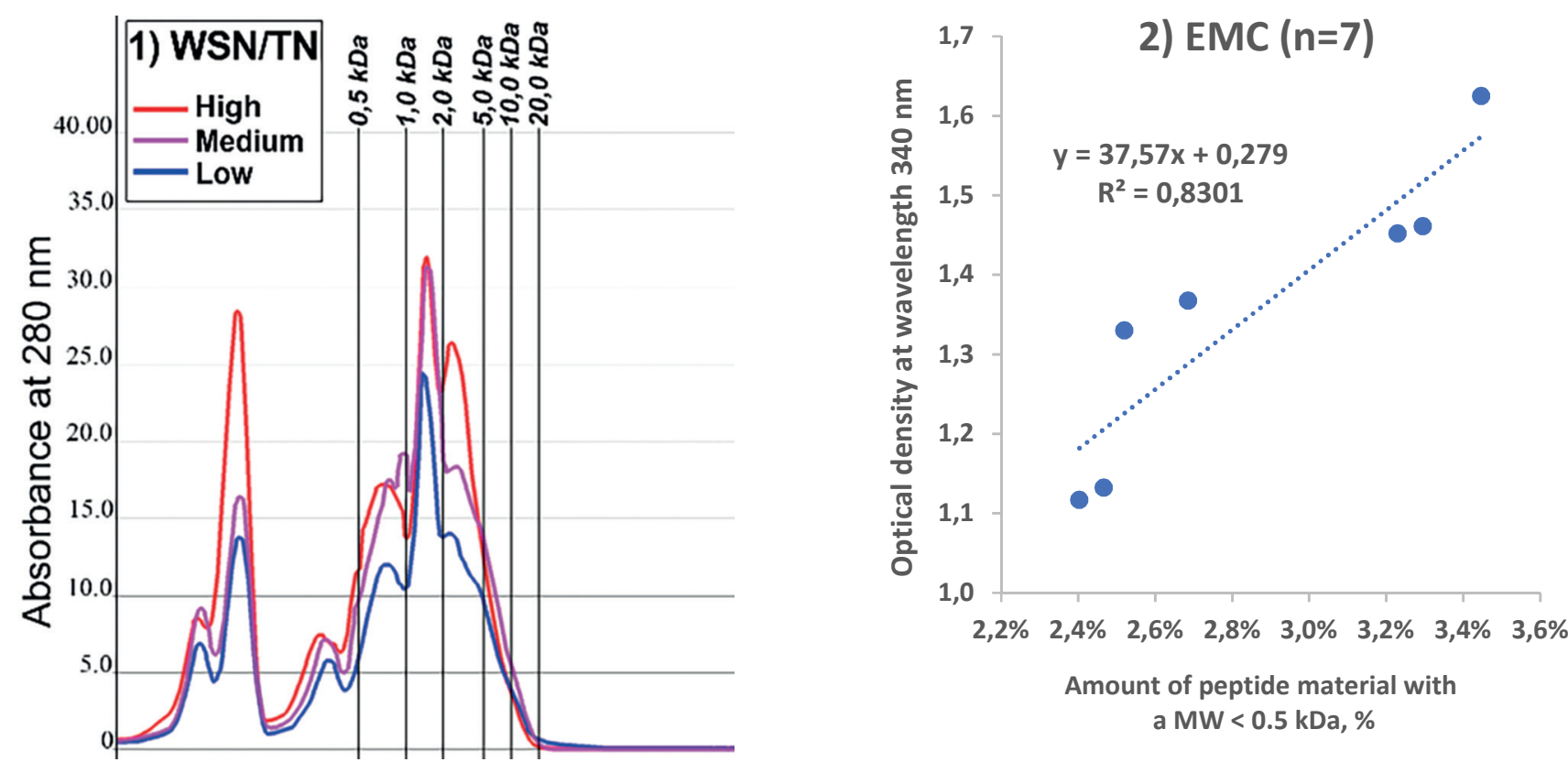

Figure 3. 1) Molecular mass distribution in EMC samples with the minimum, median and maximum levels of proteolysis in the sample: Low $(\mathrm{WSN} / \mathrm{TN}=64.5 \%) ;$ Median $(\mathrm{WSN} / \mathrm{TN}=79.2 \%)$; High $(\mathrm{WSN} / \mathrm{TN}=80.1 \%)$;

2) Dependence of the degree of staining with the OPA reagent (OD340) on the amount of peptide material with a MW $<0.5 \mathrm{kDa}$ in EMC

\section{Conclusions}

The OPA method, based on the determination of the amount of active amino groups, can be applied in practice to assess accurately the degree of proteolysis in cheeses. The OPA method gives results that strictly correlate $\left(\mathrm{R}^{2}>0.80, \mathrm{p}<0.01\right)$ with the results of assessing the degree of proteolysis by the Kjeldahl method. The results of the OPA method, expressed in the absorption intensity of the colored sample at a wavelength of 340 $\mathrm{nm}$ (OD340), can be converted to the content of soluble nitrogenous substances in cheese (WSN), using the calibration relationship between these indicators.

The accuracy of the calibration relationship between WSN and OD340 can be increased $\left(\mathrm{R}^{2}>0.91, \mathrm{p}<0.01\right)$ when using the OPA method in relation to a homogeneous group of cheeses pro- duced by the same technology using the same type of MCE and lactic acid culture and having a similar shape of molecular mass distribution of proteolysis products.

The OPA method can be used to assess the content of proteolysis products, which form cheese flavor, in EMC. The results of assessing the degree of proteolysis by the OPA method (OD340) are proportional to both the total content of soluble nitrogen and the proportion of nitrogenous substances in it with a mass of less than $0.5 \mathrm{kDa}$, which make the greatest contribution to the formation of chees flavor.

The advantage of using the OPA method for assessing proteolysis in cheeses and EMC instead of the Kjeldahl method is a simpler measurement procedure and the possibility of studying more samples in less time.

\section{REFERENSES}

1. Polychroniadou, A. (1988). A simple procedure using trinitrobenzene sulphonic acid for monitoring proteolysis in cheese. Journal of Dairy Research, 55, 585-596.

2. Samples, D.R., Richter R. L., Dill, C.W. (1984). Measuring Proteolysis in Cheddar Cheese Slurries: Comparison of Hull and Trinitrobenzene Sulfonic Acid Procedures. Journal of Dairy Science, 67, 60-63.

3. Pearce, K.N., Karahalios, D., Friedman, M. (1988). Ninhydrin assay for proteolysis in ripening cheese. Journal of Food Science, 53, 432-435, 438

4. Church, F.C., Swaisgood, H.E., Porter, D.H., Catignani, G.L. (1983). Spectrophotometric Assay Using o-Phthaldialdehyde for Determination of Proteolysis in Milk and Isolated Milk Proteins. Journal of Dairy Science, 66, 1219-1227.

5. Garbowska, M., Pluta, A., Berthold-Pluta, A. (2019). Antihypertensive Peptide Activity in Dutch-Type Cheese Models Prepared with Different Additional Strains of Lactobacillus Genus Bacteria. Applied Science, 9, 1674-1684. https://doi.org/10.3390/app9081674

6. Garde, S., Tomillo, J., Gaya, P., Medina, M., Nuñez, M. (2002). Proteolysis in Hispánico Cheese Manufactured Using a Mesophilic Starter, a Thermophilic Starter, and Bacteriocin-Producing Lactococcus lactis Subsp. lactis INIA 415 Adjunct Culture. Journal of Agricultural and Food Chemistry 50, 3479-3485.

7. Rohm, H., Tschager, E., Jaros, D. (1996). Determination of Proteolysis in Swiss Cheese: Comparison of the Kjeldahl Method and a Spectrophotometric OPA Assay. Lebensmittel-Wissenschaft und-Technologie, 29, 191-194.

8. Nielsen, P.M., Petersen, D., Dambmann, C. (2001). Improved Method for Determining Food Protein Degree of Hydrolysis. Journal of Food Science, 66(5), 642-646.

9. Silvestre, M.P.C., Morais, H.A., Silva, V.D.M., Silva, M.R. (2013). Degree of hydrolysis and peptide profile of whey proteins using pancreatin.
Brazilian Journal of Food and Nutrition, 38(3), 278-290. http://dx.doi. org/10.4322/nutrire.2013.026

10. Panasiuk, R., Amarowicz, R., Kostyra, H., Sijtsma, L. (1998). Determination of a-amino nitrogen in pea protein hydrolysates: a comparison of three analytical methods. Food Chemistry, 62(3), 363-367.

11. Myagkonosov, D.S., Mordvinova, V.A., Abramov, D.V., Ovchinnikova, E.G., Municheva, T.E. (2020). Rennet test is an important tool for producing high quality cheese. / Cheesemaking and Buttermaking, 2, 30-33. (in Russian)

12. Kilcawley, K.N., Wilkinson, M.G., Fox, P.F. (2006). A novel two-stage process for the production of enzyme-modified cheese. Food Research International, 39(5), 619-627. https://doi.org/10.1016/i.foodres.2005.12.006

13. Kuchroo, C.N., Fox, P.F. (1982). Soluble nitrogen in Cheddar cheese: Comparison of extraction procedures. Milchwissenschaft, 37, 331-335.

14. Ivens, K.O., Baumert, J.L., Hutkins, R.L., Taylor, S.L. (2017). Effect of proteolysis during Cheddar cheese aging on the detection of milk protein residues by ELISA. Journal of Dairy Science, 100, 1629-1639. https://doi. org/10.3168/jds.2016-11649

15. Visser, S., Slangen, C.J., Robben, A.J.P.M. (1992). Determination of molecular mass distributions of whey protein hydrolysates by high-performance size-exclusion chromatography. Journal of Chromatography $A$ 599(1-2), 205-209. https://doi.org/10.1016/0021-9673(92)85474-8

16. Wilkinson, M.G., Guinee, T.P., O’Callaghan, D.M., Fox, P.F. (1992). Effects of commercial enzymes on proteolysis and ripening in Cheddar cheese. Lait, 72, 449-459. https://doi.org/10.1051/lait:1992533

17. Fox, P.F., Guinee, T.P., Cogan, T.M., McSweeney, P.L.H. (2017). Biochemistry of Cheese Ripening. Chapter 12 in book: Fundamentals of Cheese Science. 2nd ed. - New York: Springer. - pp. 391-442. ISBN978-1-48997681-9 (eBook) 
18. Dekker, P. (2019). Dairy Enzymes. Chapter 2.3 in book: Industrial Enzyme Applications, (ed. Vogel A., May O.) 1st ed. - Wiley-VCH Verlag GmbH \& Co. KgaA. - pp. 143-166. ISBN 978-3-5278-1378-0 (eBook)

19. Fox P. F. O’Connor, T.P., McSweeny, P.L.H., O’Brien, N.M. (1996). Cheese: physical, biochemical, and nutritional aspects. Advances in Food and Nutrition Research, 39, 163-328. https://doi.org/10.1016/ s1043-4526(08)60075-3
20. Fox, P.F., Wallace, J.M. (1997). Formation of Flavor compounds in cheese. Advances in Applied Microbiology, 45, 17-85. https://doi.org/10.1016/ s0065-2164(08)70261-2

21. Kilcawley, K.N., Wilkinson, M.G., Fox, P.F. (2000). A survey of the composition and proteolytic indices of commercial enzyme-modified Cheddar cheese. International Dairy Journal, 10, 181-190. https://doi.org/10.1016/ S0958-6946(00)00029-7

\section{AUTHOR INFORMATION}

Dmitry S. Myagkonosov - candidate of technical sciences, leading researcher, head of research department in applied biochemistry and enzymology, All-Russian Scientific Research Institute of Butter- and Cheesemaking - Branch of V. M. Gorbatov Federal Research Center for Food Systems of RAS. 152613, Yaroslavl Region, Uglich, Krasnoarmeysky Boulevard, 19. Tel .: +7-915-973-63-13, E-mail: mds-mail@mail.ru https://orcid.org/0000-0003-4443-7573

* corresponding author

Dmitry V. Abramov - candidate of biological sciences, leading researcher, head of biochemical research in cheesemaking and buttermaking, All-Russian Scientific Research Institute of Butter- and Cheesemaking - Branch of V. M. Gorbatov Federal Research Center for Food Systems of RAS. 152613, Yaroslavl Region, Uglich, Krasnoarmeysky Boulevard, 19. Tel .: + 7-910-970-42-97, E-mail: uglich.dva@mail.ru

https://orcid.org/0000-0001-8326-1932

Elena G. Ovchinnikova - researcher, department of biochemistry, All-Russian Scientific Research Institute of Butter- and Cheesemaking - Branch of V. M. Gorbatov Federal Research Center for Food Systems of RAS. 152613, Yaroslavl Region, Uglich, Krasnoarmeysky Boulevard, 19. Tel .: + 7-48532-98-1-94, E-mail: elenna.ov@mail.ru

https://orcid.org/0000-0003-4891-4330

Valentina N. Krayushkina - junior researcher, department of biochemistry, All-Russian Scientific Research Institute of Butter- and Cheesemaking - Branch of V. M. Gorbatov Federal Research Center for Food Systems of RAS. 152613, Yaroslavl Region, Uglich, Krasnoarmeysky Boulevard, 19. Tel.: +7-48532-98-1-33, E-mail: uglich-cheese@mail.ru

https://orcid.org/0000-0002-4904-6152

All authors bear responsibility for the work and presented data.

All authors made an equal contribution to the work.

The authors were equally involved in writing the manuscript and bear the equal responsibility for plagiarism.

The authors declare no conflict of interest.

Received 30.10.2020 Accepted in revised 01.12.2020 Accepted for publication 22.12.2020 